\title{
Introduction to the Special Issue "Seafloor backscatter data from swath mapping echosounders: from technological development to novel applications"
}

\author{
Geoffroy Lamarche ${ }^{1,2} \cdot$ Xavier Lurton ${ }^{3}$
}

Published online: 28 March 2018

๑) Springer Science+Business Media B.V., part of Springer Nature 2018

Exploration, mapping and monitoring of the seafloor have vastly evolved over the last few decades following the introduction of multibeam echosounders (MBES). This has resulted in substantial advance in the qualitative and quantitative use of bathymetric data for a wide variety of applications. However, engineers, operators, and scientists working on MBES seafloor data recognize today the need for better coherence and agreement on backscatter data acquisition, processing and interpretation procedures.

In May 2013, a group of marine scientists, spatial analysts as well as manufacturers and software developers for seafloor-mapping sonars met at the Marine Geological and Habitat Mapping (http://www.Geohab.org) conference in Rome and set up the international Backscatter Working Group (BSWG). The founding idea of the BSWG originates from a realisation of a patent lack of commonly accepted methodologies. The working group thrived under a dynamic leading group and the vision that "backscatter data acquired from differing sonar systems, or processed through differing software tools, must generate consistent values over a same area under the same conditions; these data are scientifically meaningful and usable by end-users from all application domains (geoscience, environment, hydrography, industry, fisheries, monitoring, cultural...)".

In May 2015, the BSWG released the first set of guidelines for acquisition, processing and use of backscatter data (Lurton and Lamarche 2015), which provided recommendations for further development of backscatter acquisition

Geoffroy Lamarche

geoffroy.lamarche@niwa.co.nz

1 NIWA, 301 Evans Bay Parade, Wellington 6021, New Zealand

2 School of Environment, University of Auckland, Auckland, New Zealand

3 IFREMER, CS 10070, 29280 Plouzané, France systems and processing software. The document was very well received by the relevant community and is now used by universities, government organizations, software companies and research institutions. This motivated us to propose this special issue of Marine Geophysical Research, following on the work of the BSWG.

This "Backscatter" Special Issue includes 19 manuscripts involving 68 authors from 34 different research and government organizations as well as marine surveying, software development companies and sonar manufacturers. It is opened by a synthesis paper (Lamarche and Lurton 2017) presenting the novelty of seafloor backscatter and summarizing the main recommendations about backscatter acquisition and processing, as expressed in more details inside the original BSWG report.

The 19 papers are organized in four groups addressing the following wide-ranging areas of research and development: (1) status and expectations (2 papers), (2) sonar calibration (5 papers); (3) backscatter data processing and uncertainty (5 papers); and (4) applications and new developments (7 papers).

A key issue, persistently cited by users and developers is the absence of systematic calibration of equipment and data; this was clearly raised in a survey in which users and stakeholders expressed their views and concerns on this topic (Lucieer et al. 2017). This is addressed here in several papers, mostly focusing on the use of field data from controlled seafloor areas making it possible to practically calibrate MBES under operational conditions: Eleftherakis et al. (2018), Ladroit et al. (2017) and Weber et al. (2017) promote-with some variants - the cross-calibration of MBES with a tilted calibrated fishery-type single-beam echosounder. Wendelboe (2018) presents results from a MBES calibrated by metrological methods. The procedures, advantage and issues of relative calibration of data using natural reference areas (Roche et al. 2018) or multiple surveying 
on dedicated lines (Weber et al. 2017) are presented and discussed, illustrated by field data from such potential sites.

Backscatter data processing remains a relatively novel domain, implying a complex chain of processing operations. The overview of this topic provided by Schimel et al. (2018), with a focus on sonar calibration, demonstrates that backscatter processing is still prone to evolve and to incorporate innovative approaches. Fonseca et al. (2017) propose a filtering method compensating the slow along-track modulation artifacts caused by ship's motion. Mitchell et al. (2018) apply MBES-measured reflectivity to the detection of seepages from the seafloor, emphasizing the need for preliminary balancing of the sensor directivity pattern and the interest of redundant insonification using overlapping survey tracks. Fezzani and Berger (2018) propose an original method of simplified segmentation and classification based on a large dataset of calibrated field data.

The accuracy of backscatter field data remains poorly quantified: Malik et al. (2018) investigate its uncertainty causes and magnitudes, both from instrumental and environmental origin.

Understanding specific physical phenomena and their impact on backscatter measurement is still a paramount issue-namely the penetration of the signal beneath the seafloor interface (Hillman et al. 2017; Alevizos et al. 2017; Lacharité et al. 2017) and the azimuth dependence caused by roughness polarization commonly observed in coastal areas (Lurton et al. 2017). Comparing and combining data originating from different sources can be challenging but is necessary to e.g., optimize results or completeness of coverage (Ierodiaconou et al. 2017; Lacharité et al. 2017). Finally, the frequency dependence of seafloor response is obviously a key issue, susceptible of innovative applications; this topic is addressed by Wendelboe (2018), by Weber et al. (2017), and mentioned by Eleftherakis et al (2018).

Habitat mapping and environment monitoring are two of the most promising applications of seafloor backscatter, the data of which provide a valuable, independent proxy for substrate; this approach is now frequently used in predictive substrate and habitat mapping in shallow (Ierodiaconou et al. 2017; Montereale-Gavazzi et al. 2017; Siwabessy et al. 2017) or deep water (Hillman et al. 2017) environments.

An important feature of seafloor backscatter data is the echo level dependence on incidence angle. Although known for long time in principle, this approach is not yet fully mature and requires development before delivering its full potential. Here the impact of survey directions on backscatter intensity (Lurton et al. 2017) or incidence angle on the seafloor (Alevizos et al. 2017) are taken into consideration for developing improved survey design, data acquisition procedure and interpretation potential. Finally, the use of water column backscatter data accessible to the new MBES generation is presented as an opening to the nascent water-column imaging area of technology and research by Mitchell et al. (2018), who also emphasize the need for directivity pattern balancing and the redundant insonification from overlapping survey tracks.

We see this special issue as a successful test of the recommendations of the Backscatter Working Group (Lurton and Lamarche 2015), and we hope it gives to the community a clear overview of the status of this topic of MBES-measured seafloor backscatter applied to marine habitat mapping and more generally to oceanography.

Acknowledgements Working through this Special Issue was made possible thanks to the support and hard work of the leading group of the BSWG, Tom Weber, Vanessa Lucieer, Glen Rice, Craig Brown, Alexandre Schimel and Erin Heffron. We wish to thank the reviewers that have contributed to develop a strong Special Issue and-indeed, all authors and co-authors who published in this issue. This work was supported by the New Zealand Strategic Science Investment Fund's programme "Marine Geological Processes and Resources" (COPR1703) of NIWA and the R\&D programme "Underwater Acoustics" (R403-06) of Ifremer.

\section{References}

Alevizos E, Snellen M, Simons DG, Siemes K, Greinert J (2017) Multi-angle backscatter classification and sub-bottom profiling for improved seafloor characterization. In: Lamarche G, Lurton X (eds) Marine Geophysical Research, Seafloor backscatter data from swath mapping echosounders: from technological development to novel applications (this issue). https://doi.org/10.1007/ s11001-017-9325-4

Eleftherakis D, Berger L, Le Bouffant N, Pacault A, Augustin J-M, Lurton X (2018) Backscatter calibration of high-frequency multibeam echosounder using a reference single-beam system, on natural seafloor. In: Lamarche G, Lurton X (eds) Marine Geophysical Research, Seafloor backscatter data from swath mapping echosounders: from technological development to novel applications (this issue). https://doi.org/10.1007/s11001-018-9348-5

Fezzani R, Berger L (2018) Analysis of calibrated seafloor backscatter for habitat classification methodology and case study of 158 spots in the Bay of Biscay and Celtic Sea. In: Lamarche G, Lurton X (eds) Marine Geophysical Research, Seafloor backscatter data from swath mapping echosounders: from technological development to novel applications (this issue). https://doi.org/10.1007/ s11001-018-9342-y

Fonseca L, Hung EM, Ayres-Neto A, Magrani FJG (2017) Waterfall notch-filtering for restoration of acoustic backscatter records from Admiralty Bay, Antarctica. In: Lamarche G, Lurton X (eds) Marine Geophysical Research, Seafloor backscatter data from swath mapping echosounders: from technological development to novel applications (this issue). https://doi.org/10.1007/s1100 1-017-9330-7

Hillman J, Lamarche G, Pallentin A, Pecher I, Gorman A, Schneider von Deimling J (2017) Validation of automated supervised segmentation of multibeam backscatter data from the Chatham Rise, New Zealand. In: Lamarche G, Lurton X (eds) Marine Geophysical Research, Seafloor backscatter data from swath mapping echosounders: from technological development to novel applications (this issue). https://doi.org/10.1007/s11001-016-9297-9

Ierodiaconou D, Schimel A, Diesing M, Monk J, Rattray A, Kennedy D, Young M, Gaylard G (2017) Combining pixel and object based 
image analysis of ultra-high resolution multibeam bathymetry and backscatter for habitat mapping in shallow marine waters. In: Lamarche G, Lurton X (eds) Marine Geophysical Research, Seafloor backscatter data from swath mapping echosounders: from technological development to novel applications (this issue). https ://doi.org/10.1007/s11001-017-9338-z

Lacharité M, Brown C, Gazzola V (2017) Multisource multibeam backscatter data: developing a strategy for the production of benthic habitat maps using semi-automated seafloor classification methods. In: Lamarche G, Lurton X (eds) Marine Geophysical Research, Seafloor backscatter data from swath mapping echosounders: from technological development to novel applications (this issue). https://doi.org/10.1007/s11001-017-9331-6

Ladroit Y, Lamarche G, Pallentin A (2017) Seafloor multibeam backscatter calibration experiment: comparing $45^{\circ}$-tilted $38-\mathrm{kHz}$ splitbeam echosounder and 30-kHz multibeam data. In: Lamarche G, Lurton X (eds) Marine Geophysical Research, Seafloor backscatter data from swath mapping echosounders: from technological development to novel applications (this issue). https://doi. org/10.1007/s11001-017-9340-5

Lamarche G, Lurton X (2017) Recommendations for improved and coherent acquisition and processing of backscatter data from seafloor-mapping sonars. In: Lamarche G, Lurton X (eds) Marine Geophysical Research, Seafloor backscatter data from swath mapping echosounders: from technological development to novel applications (this issue). https://doi.org/10.1007/s1100 1-017-9315-6

Lucieer V, Roche M, Degrendele K, Malik M, Dolan M, Lamarche G (2017) User expectations for multibeam echo sounders backscatter strength data-looking back into the future. In: Lamarche G, Lurton X (eds) Marine Geophysical Research, Seafloor backscatter data from swath mapping echosounders: from technological development to novel applications (this issue). https://doi.org/10.1007/ s11001-017-9316-5

Lurton X, Lamarche G (eds) (2015) Backscatter measurements by seafloor-mapping sonars. Guidelines and recommendations. Geohab report. http://geohab.org/wp-content/uploads/2013/02/ BWSG-REPORT-MAY2015.pdf

Lurton X, Eleftherakis D, Augustin J-M (2017) Analysis of seafloor backscatter strength dependence on the survey azimuth using multibeam echosounder data. In: Lamarche G, Lurton X (eds) Marine Geophysical Research, Seafloor backscatter data from swath mapping echosounders: from technological development to novel applications (this issue). https://doi.org/10.1007/s1100 1-017-9318-3

Malik M, Lurton X, Mayer L (2018) A framework to quantify uncertainties of seafloor backscatter from swath mapping echosounders. In: Lamarche G, Lurton X (eds) Marine Geophysical Research, Seafloor backscatter data from swath mapping echosounders: from technological development to novel applications (this issue). https ://doi.org/10.1007/s11001-018-9346-7
Mitchell G, Orange D, Gharib J, Kennedy P (2018) Improved detection and mapping of deepwater hydrocarbon seeps: Optimizing multibeam echosounder seafloor backscatter acquisition and processing techniques for marine seep hunting. In: Lamarche G, Lurton X (eds) Marine Geophysical Research, Seafloor backscatter data from swath mapping echosounders: from technological development to novel applications (this issue). https://doi.org/10.1007/ s11001-018-9345-8

Montereale-Gavazzi G, Roche M, Lurton X, Degrendele K, Terseleer N, Van Lancker V (2017) Seafloor Change Detection Using multibeam echosounder backscatter: case study on the Belgian part of the North Sea. In: Lamarche G, Lurton X (eds) Marine Geophysical Research, Seafloor backscatter data from swath mapping echosounders: from technological development to novel applications (this issue). https://doi.org/10.1007/s11001-017-9323-6

Roche M, Degrendele K, Vrignaud C, Loyer S, Le Bas T, Eleftherakis D, Augustin J-M, Lurton X (2018) Control of the repeatability of high frequency multibeam echosounder backscatter by using natural reference areas. In: Lamarche G, Lurton X (eds) Marine Geophysical Research, Seafloor backscatter data from swath mapping echosounders: from technological development to novel applications (this issue). https://doi.org/10.1007/s11001-018-9343-x

Schimel A, Beaudoin J, Parnum I, Le Bas T, Schmidt V, Keith G, Ierodiaconou D (2018) Multibeam sonar backscatter data processing. In: Lamarche G, Lurton X (eds) Marine Geophysical Research, Seafloor backscatter data from swath mapping echosounders: from technological development to novel applications (this issue). https ://doi.org/10.1007/s11001-018-9341-Z

Siwabessy PJ, Tran M, Picard K, Brooke BP, Huang Z, Smit N, Williams DK, Nicholas WA, Nichol SL, Atkinson I (2017) Modelling the distribution of hard seabed using calibrated multibeam acoustic backscatter data in a tropical, macrotidal embayment: Darwin Harbour, Australia. In: Lamarche G, Lurton X (eds) Marine Geophysical Research, Seafloor backscatter data from swath mapping echosounders: from technological development to novel applications (this issue). https://doi.org/10.1007/s11001-017-9314-7

Weber T, Rice G, Smith M (2017) Toward a standard line for use in multibeam echo sounder calibration. In: Lamarche G, Lurton X (eds) Marine Geophysical Research, Seafloor backscatter data from swath mapping echosounders: from technological development to novel applications (this issue). https://doi.org/10.1007/ s11001-017-9334-3

Wendelboe G (2018) Backscattering from a sandy seabed measured by a calibrated multibeam echosounder in the $190-400 \mathrm{kHz}$ frequency range. In: Lamarche G, Lurton X (eds) Marine Geophysical Research, Seafloor backscatter data from swath mapping echosounders: from technological development to novel applications (this issue). https://doi.org/10.1007/s11001-018-9350-y 